\section{A GLANCE INTO THE LIFE OF A COMPUTERIZED GENERATION: A CASE STUDY ON THAI TEENAGERS LIVING IN BANGKOK}

\section{Chulanee Thianthai $^{1}$}

\begin{abstract}
In this fast paced world, computer and internet use have automatically become an essential part of metropolitan life. It is easy for those who were born in the older generation to notice the impact of computers and internet on themselves, but what about this young generation of Thai teenagers who are growing up in a computerized generation? What computerrelated behavioral aspects do these teenagers find to be unique for their generation? In seeking the answer to this question, this study aims to explore six different areas. Topics of discussion concern: (1) Thai teenagers define their computerized generation; (2) The computerized generation's daily life activities; (3) The symbolic meanings of computers and the feelings of being in cyberspace; (4) Characteristics and concepts Thai teenagers use to identify as computer and internet-related influences on their generation; (5) Responding to common false myths concerning teenagers and computer use in Thai society; (6) Foreseeing their future living with computers and advance technologies. Data were collected from among sixty male and female high school
\end{abstract}

\footnotetext{
${ }^{1}$ Department of Sociology and Anthropology, Faculty of Political Science, Chulalongkorn University
}

students, age 16-19, in four different public schools in Bangkok. Anthropological research methods, namely participant observation, survey questionnaire, and indepth interviews were utilized in order to achieve these study objectives.

\section{Introduction}

From the abacuses to eyeglasses, computers and the recent development of artificial intelligence robots, humans have used their imaginations to improve their creations, to learn from them, as well as be affected by them. Throughout time man's inventions have been perceived to be an inseparable part of human evolution. We are moving towards the era of computerization. Along with being able to read, write, and calculate, computer literacy has become one of the most important skills that people of this generation need to have (Komonmas 1991).

Computerization began in Thailand in 1964 when the first two computers were brought into the country to be used in the National Statistical Office and Chulalongkorn University (Tiotuyco and Vichyanond 1985; Komonmas 1991; Malaiwong et. al.1998). Ten years later the demand for imported computers in Thailand had increased in both the public and private sectors at an annual rate of up to $75 \%$ (Tiotuyco and Vichyanond; 1985). Universal Automatic Computer (UNIVAC, now known as IBM), Apple, NCR, CDC, and Compact were the first groups of computer manufacturers that had made their way into the Thai market (Komonmas 1991).

At present, computer usage in Thailand has come to a fourth wave. In Changwattanachai's article written in 1991, he describes the evolution of computer usage in Thailand and divided it into four periods 
of time. In the first wave, computers in Thailand were being used for routine statistical entry work. Then computers were used for management of information systems in private organizations in the second wave. They helped many managers analyze data, made important company decisions, and predicted future trends. In the third wave, computers had improved its capability in terms of becoming much faster, being more friendly to the user, and most of all, equipped with accessories (e.g. diskette) that could transfer what was being saved onto another computer. This third wave was the "decision support system age." The fourth and present wave of computerization in Thailand has now entered the era of utilizing computers as a way to communicate and get connected to the world. A study conducted by NECTEC in 2004 predicted that by the year 2005 over 6 million Thai people will use the Internet (The Internet Index of Thailand [online] 2004). Moreover, many high-technology related computing options, such as electronic mailing system (e-mail), tele-conference, and special purpose computers, have been created to serve people in all occupations and age groups. These types of waves might occur similarly to other countries, but there are also variations that could be found.

Much research has shown usage of computer-related variations can occur in many forms: differences of computer usage occur in each gender, class, age, and level of education, and can even be found between developed and developing countries (NECTEC 1999; Pondper 1999; Puntawee 1999; Chaisakda 2002; Information Technology Report Column 2003; Srisuttipan 2002). While developed countries use the Internet mainly for communicating, developing countries are likely to use the Internet for information purposes. Thailand seems to fall in between the developed and developing country's category; that is, they use the Internet as a means for communicating through e-mail as well as searching for information (Pondper 1999). In Thailand, teenagers ranging in age from 15-19 were found to be the age group who uses the Internet the most (The Survey of Information Technology 2003). There is also a significant difference in how each age group perceives and uses their computers in their everyday life (www.thaiparents.net 2002). For example, children use computers to play games, teenagers use them to get connected to the world and to make new friends in chat rooms, adults use them for work and to search for data, and the elderly use them indirectly as health equipment (Sarawut 2003; Sripetchnai 2004; Theppipit 1990; Jirapinnusorn 1997; Srisab 1999). Likewise, there is also a difference between generations, those who were born before the computerization age and those in the computerized generation; that is, while the former tends to use their Internet for taskoriented goals, the latter age group uses the Internet to entertain themselves or serve their interests (Paratasillapin 2001).

But what is it really like to grow up in the computerized generation? There are a few studies and books written based on what has happened in Western society (Tapscott 1998; Anderson and Tracey 2001; Williams 2002). Rarely have there been studies conducted among the computerized generation who live in a transitional society in Asia. The author aims to use this research to fill this gap. This research will explore the unique characteristics of this new generation of Thai teenagers that are growing up in the computerization era. In addition, this research also aims to provide the readers with insight into what computers mean to them, what their daily Internet-related activities are, and how they foresee 
themselves living in the future of advanced computer technology.

\section{Setting, population, and research methodology}

This qualitative research was conducted in Bangkok, known as the city of angels. Bangkok, the capital of Thailand, is where the social lives of the city people, business flow, important political institutions, and high technology advancement is located. In order to study the lives of a computerized generation, Bangkok is a perfect setting for this research objective. The intensive data collection was gathered during OctoberDecember of 2004. Sixty male and sixty female middle to upper class high school students, who were born in the years 19881991, when computers started becoming an essential part of urban living, were invited to join in this study. These teenagers came from four different public high schools in central Bangkok.

Ethnographic research techniques, namely, participant observation, interview questionnaires, in-depth interview, pictorial ethnography, and secondary data research helped conceptualize some of the important aspects of the computerized generation. First, the author observed different types of computer and Internet techno-related activities Thai teenagers engaged in. Secondary research techniques, such as reading former studies, Thai newspapers, books, and computer-related articles, also helped in understanding how computers have had an impact on both this age group as well as on Thai society. Information gained from both of these research techniques was used to form the structured questions of an interview questionnaire.

One hundred and twenty interview questionnaires were handed out to students in accordance to the purposive and snowball sampling techniques. The interview questionnaires were composed of three sections. The first section consisted of demographic questions, such as age, year born, gender, level of parents' income, level of education, level of parents' education, and number and ownership of a computer at home. The raw data was coded and entered in the SPSS program to show the demographic characteristics of the sample population. The second section of the questionnaire covered open-ended questions aimed at answering each of the research objective questions. Pictorial ethnography technique was combined with the third section of the interview questionnaire. The third section of the questionnaire was a blank page for students to draw pictures and describe how they foresee their future, living with computer and high-technology. After the picture was drawn, the author would ask the students to explain the pictures in their own words, presenting their imaginations through verbal conversation, through exploring and devouring on the drawings they had drawn.

The author selected thirty students who filled in interesting information in the questionnaires as well as showed interest and willingness to participate in an in-depth interview. The author used interviews to dig deep into these interesting answers and clarify some of the information that was unclear. In-depth interviews helped provide rich information of how the students perceive their generation to be different from other generations.

The author then selected eight people out of thirty students who participated in the indepth interviews as specific case studies. The participant observation technique was used in following the lives of these eight students. The author aimed at being 
involved in learning the computer-related activities of these students, such as chatting, finding friends in chat rooms, and pursuing their interests on their favorite websites.

Table 1: The number of participants participating in each research methodology

\begin{tabular}{|l|l|}
\hline \multicolumn{1}{|c|}{ Research Techniques } & \multicolumn{1}{c|}{ Number of Participants } \\
\hline Interview questionnaires & 120 participants \\
\hline In-depth interviews & 30 participants \\
\hline Intensive participant observation case studies & 8 participants \\
\hline Total & $\mathbf{1 2 0}$ participants* \\
\hline
\end{tabular}

Notice: * Teenagers who participated in indepth interview and represent intensive participant observation case studies were among the same group of teenagers who participated in the initial interview questionnaire.

To keep the student's personal data confidential, all names mentioned in this research are replaced by pseudonyms.

\section{Discussion}

\section{Being one of the computerized generation}

When asked to join in this study, there were no doubts or second thoughts from these Thai teenagers about their being part of the computerized generation. Many were asked what the net generation is, and how the computerized generation different is from the generation of their parents, like the baby boomers. The author thinks that the answers to these questions are much clearer, be her explain, and amusing from these teenagers' own words.

Researcher: Please describe and define the children of the computerized generation?

Teenagers: The children who grew up in the computerized generation are...
Those who prefer to use computers for entertainment more than to go out, run round, and play with friends outside the house.

Those who live a convenient life and use technology heavily in their everyday lives.

Those who can think, develop their thoughts, keep up with new technology, and are able to use technology in a beneficial and moral way.

Those who live and Interact with others (human) in both real society and through the internet community.

Those who think that it is necessary to use computers in their daily lives for doing things for themselves, including using it for relaxation.

Those who were born and grew up in a society that uses advanced technology. Everything that they do from the time they were born till the time they die involve technology and computer control.

The generation who can utilize computers the most. 
The new generation have no boundaries of thought have, freedom in expressing themselves, and are able to form infinite numbers of networks through cyberspace.

Those who use computers a lot and cannot live without them.

Those who are modern and advanced people who can keep up with the world at just one touch of the computer in their home.

Those who have computers and know what Internet means.

Above were selected answers that came from Thai teenagers most of which represent these common themes. Although these teenagers might not be familiar with the phrase "computerized generation" that refers to their generation image, they have a pretty good idea of what their generation is. Not only a contrast between different' $\mathrm{s}$ generation thoughts, feelings, abilities, and activities, but also some of the descriptions make us think about how in the real world there is also a digital gap between those teenagers who have access to this technology and those who have not.

\section{Daily life activities of the computerized generation}

Living in the computerized generation means more than just being surrounded by advanced technologies and computer gadgets. To these students, it means that technology and they are inseparable in their everyday activities. As far back as they can remember, their parents have used technology to raise them, and they learned to use it, and accepted it as a part of their routine. Just like learning to brush their teeth everyday in the morning. It is very normal and natural. This is because technology has always been there for their generation. Therefore, it is not surprising that during the interviews, it was hard for these teenagers to name their activities associated with technology and computerrelated gadgets. However, when given time to think of their daily schedule, they came to realize the enormous involvement between themselves and their reliability on these high-tech instruments. 
Table 2: Two of the examples of the computerized generation's daily life on the weekday (left) and weekend (right).

\begin{tabular}{|c|c|}
\hline & Monday-Friday \\
\hline Time & $\begin{array}{l}\text { Technology and Computer-related } \\
\text { Activities }\end{array}$ \\
\hline \multirow{3}{*}{$\begin{array}{l}6.20- \\
7 \mathrm{am}\end{array}$} & Waking up because of digital alarm clock \\
\hline & Using electric tooth brush \\
\hline & Taking a water heated shower \\
\hline \multirow{3}{*}{$\begin{array}{l}7.00- \\
7.40 \\
\text { am. }\end{array}$} & $\begin{array}{l}\text { Driving to school or taking BTS then bus } \\
\text { to school }\end{array}$ \\
\hline & $\begin{array}{l}\text { Viewing electronic billboards on BTS } \\
\text { platform or the new time reduction traffic } \\
\text { lights }\end{array}$ \\
\hline & $\begin{array}{l}\text { Listening to music on the car radio or } \\
\text { using portable MP3 walkman radio }\end{array}$ \\
\hline \multirow{3}{*}{$\begin{array}{l}8.10- \\
11.50 \\
\text { am. }\end{array}$} & Using lift to the classroom \\
\hline & $\begin{array}{l}\text { Turning on lights, air conditioning, and } \\
\text { sound system/microphone in classroom }\end{array}$ \\
\hline & Drinking water from a drinking fountain \\
\hline \multirow[t]{3}{*}{$\begin{array}{c}11.50-1 \\
\text { pm. }\end{array}$} & $\begin{array}{l}\text { Eating school meals or Western food sold } \\
\text { at school usually cooked by electronic } \\
\text { cooking appliances }\end{array}$ \\
\hline & $\begin{array}{l}\text { Calling friends from cell phone/sending } \\
\text { messages }\end{array}$ \\
\hline & $\begin{array}{l}\text { Playing games or use computer chat } \\
\text { program }\end{array}$ \\
\hline $\begin{array}{l}1-4 \\
\text { pm. }\end{array}$ & Similar to $8.10-11.50 \mathrm{am}$. activities \\
\hline \multirow[t]{4}{*}{$\begin{array}{l}4-8 \\
\mathrm{pm} .\end{array}$} & $\begin{array}{l}\text { Using cell phone to call or receive calls } \\
\text { from parents/ friends }\end{array}$ \\
\hline & Taking a car, bus, BTS back home \\
\hline & Turning on air conditioning at home \\
\hline & $\begin{array}{l}\text { Eating dinner with family where most of } \\
\text { the electric kitchen appliances are used }\end{array}$ \\
\hline \multirow[t]{3}{*}{$\begin{array}{l}8-10.30 \\
\text { pm. }\end{array}$} & $\begin{array}{l}\text { Watching/listening to channel V or Mtv } \\
\text { channels and doing other things }\end{array}$ \\
\hline & Taking a shower/ using razor \\
\hline & $\begin{array}{l}\text { Turning on computer to chat, play games, } \\
\text { search/print information for school report }\end{array}$ \\
\hline
\end{tabular}

\begin{tabular}{|c|c|}
\hline & Saturday-Sunday \\
\hline Time & $\begin{array}{c}\text { Technology and Computer-related } \\
\text { Activities }\end{array}$ \\
\hline \multirow[t]{3}{*}{ 7-9 am. } & Taking a water-heated shower \\
\hline & Reheating food in microwave \\
\hline & Turning on the television \\
\hline \multirow{2}{*}{$\begin{array}{c}9.30- \\
11.00 \\
\text { am. }\end{array}$} & Taking the BTS to tutorial classes \\
\hline & $\begin{array}{l}\text { Learning tutorial lessons through } \\
\text { videotape }\end{array}$ \\
\hline \multirow[t]{2}{*}{$\begin{array}{l}11 \mathrm{am} .- \\
2 \mathrm{pm} .\end{array}$} & $\begin{array}{l}\text { Eating lunch and buying fashionable fruit- } \\
\text { blended drinks at Siam Square }\end{array}$ \\
\hline & $\begin{array}{l}\text { Maybe going to the movie theater with } \\
\text { friends }\end{array}$ \\
\hline \multirow{4}{*}{$\begin{array}{l}3-5 \\
\text { pm. }\end{array}$} & Taking BTS home \\
\hline & $\begin{array}{l}\text { Turning on air conditioning and calling } \\
\text { friends }\end{array}$ \\
\hline & $\begin{array}{l}\text { Watching television or playing DVD, } \\
\text { Listening to the radio or playing CD }\end{array}$ \\
\hline & Surfing Internet, checking e-mail \\
\hline $\begin{array}{l}5-7 \\
\text { pm. }\end{array}$ & $\begin{array}{l}\text { Doing homework with the help of } \\
\text { computer in searching for data }\end{array}$ \\
\hline $\begin{array}{l}7-9 \\
\text { pm. }\end{array}$ & Driving out for a family dinner \\
\hline $\begin{array}{l}9-10 \\
\text { pm. }\end{array}$ & Taking a shower and blow-drying hair \\
\hline \multirow{2}{*}{$\begin{array}{c}10- \\
11.30 \\
\mathrm{pm} .\end{array}$} & $\begin{array}{l}\text { Surfing Internet browsing through } \\
\text { favorite websites }\end{array}$ \\
\hline & Using Internet to chat with friends \\
\hline
\end{tabular}


The daily life activities of the computerized generation were not much different between the weekday and weekend. The type of technology and computer-related activities are slightly different according to socioeconomic levels of each household and each gender group. Teenagers whose parents have less income may live life with fewer types of convenient technologies than those whose parents have higher incomes. While some girls like to chat and send messages through (MSN) Internet to friends, most boys prefer to play online games. Overall, this group of teenagers often spend 2-4 hours per day using a computer. The majority teenager from this study has at least one computer at home. Only three did not. However, they are planning to buy one soon. The computer is found in every room in the household-of in their bedroom, their parent's room, living room, guestroom, their family study room, even some reported that their parents had left an old one in the storage room of there house.

These Thai teenagers felt that they are blessed to be born with these technologies. In Thai society, we often throw around words like "information technology" every now and then. The Thai sense of what technology means to this generation has extended to mean more than just things that were invented by human beings. Technology to them has transformed into various shapes of creations that are made from fundamental applied science knowledge, which are put to use to benefit human living conditions. The word "technology" also equates to things that are new, different, modern, useful innovations developed from older versions, show progress through time, facilitate and make things much faster and easier, and serve human needs. Technologies that most fascinate these teenagers are computers, cloning, nanotechnology, walking and talking robots, cell phones that can take pictures and connect to the Internet, Blue tooth technology, modern space shuttles, the invention of Internet, MSN, the new Sony walkman CD player, i-Pod, and new movie stimulation, including James Bond's detective gadgets.

Almost all of the students in this study think that adults use computers differently from their generation. For example, adults often use a computer as a type of working machine especially used for typing and making presentations, whereas teenagers use computers for multi-purposes, especially for personal entertainment, searching for information, communicating with friends, and to open up their minds to the outside world. Since computer usage by adults is more work or business orientated, adults seem to use computers to earn more money, whereas teenagers time in using computers is often related to spending (time and sometimes money). Most adults usually spend quality time and less time on their computer, only when it is necessary, whereas, teenagers use them for a long time every day. Many adults view computers as a source of information, but sometimes these teenagers view computers as a time killer for nonsense usage. Moreover, teenagers think that adults are fixated on the old computer programs they are familiar with and, unlike themselves, are reluctant to learn to use new programs.

These Thai teenagers seem to be born with special talents in making the most out of computer usage and using it for multipurposes. The types of activities include communicating through e-mail, chating, MSN and ICQ using, typing, calculating, searching for information for reports, submitting homework to teachers, working on a part-time data entry job, studying 
online, playing online games, making new designs, finding pictures for art projects or presentations, making a personal diary and picture online album, listening or loading music/ring tones, reading online newspapers, looking up new fashion trends, checking movie schedules, reading websites that have cartoons and transcribed Korean and Chinese novels, keeping up with entertainment news and celebrity gossip, making new friends, dating, voting and expressing their opinions on societal issues on webboards, selling things, consulting problems on anonymous online services, watching movies or television clips, downloading new programs, and building their own websites.

\section{The symbolic meanings of computer and the feeling of being in cyberspace}

"The Computer is my partner both at work and at play"

Prim, a 15 years old, very talkative female student

"The Computer is a part of my life, my heart and my soul"

Kang, a 17 years old male high school student

To these Thai teenagers, computers are more than just a machine. Computers are their technological friends, which help entertain them and relax, get their jobs done, relieve stress, and especially cure their boredom and loneliness. Other than catering to their everyday needs, computers help make their lives more convenient. Using computers made them feel that they were a part of the future generation that is modern, independent, clever, smart, intelligent, and in the same group as intrend people. Unlike other advanced technologies, the interaction they have with computers is much easier and more user friendly. Like playing with your extraordinary friends, they can feel excitement, a rush, and happiness.

Their sense of self in cyberspace also provides them with unique feelings. Although cyberspace is such an abstract concept when it comes to explaining and imagining being in the universe, Thai teenagers can feel the existence of it, as if they are in another world. In this study, only a couple of teenagers stated that cyberspace to them is just another space in time where they did not feel anything special. The majority of the teenagers described their experiences in cyberspace as extraordinary:

"It is my private world where I can expose my real being and freedom. I can do anything I want. Nobody knows who I am. It is like being in another world"

Tuta, a 15 year old, female high school student

"I feel good, it is fun...it is really a fun place to meet new friends."

Off, a shy 17 year old, tenth grade male student

"It is fun, like being in a very large space with an infinite boundary."

Wit, a 19 year old boy

"I can feel the excitement of seeing new things in cyberspace."

Pam, a twelfth grade high school student

"So fun to be in it that it makes me forget time."

Oat, a 16 year old girl who likes to chat on the Internet 
As we can see, cyberspace is a new spacescape made for today's generation. Teenagers like it because they can explore themselves, no boundaries, and it is unpredictable as to what they will find in this world. The feeling of being in cyberspace and the symbolic meanings of computers are closely related to one another. Computers serve as a media that transfers these teenagers to another world and transforms their imaginations into visual substance. In this other world, the world of cyberspace, they can enjoy themselves, make their own rules, and have control over it. Learning how these teenagers perceive computers and give meaning to cyberspace is among the first steps in providing a deeper understanding of the computerized generation.

\section{Conceptualizing the influence of computers on the Thai computerized generation's characteristics}

People of each generation tend to have certain shared characteristics. The usage of computers and Internet has affected the ways this generation think and act. Through participant observation, data gained from interview questionnaires and in-depth interviews, the author has noted several computer and Internet influences on the young Thai generation, which are distinct from other generations as seen below.

\section{Like interactive technology and like having control over things}

Teenagers stated that it is more fun to use interactive technology. This is a huge part of why they love computers so much, because most of the computer-related activities are interactive, such as chatting, sending messages back and forth with their friends, and playing online games.
Technology that provides a one-way interaction like radio or television seems to have decreased in popularity when compared to computers. Moreover, this generation likes to be in charge and take control over technology. They like to be active and be the planner, not the passive follower.

\section{Create their own private world}

Although the teenage years is the age when one likes to have one's own privacy, for this new generation they want even more. Using the computer a lot has kept them from outside activities with friends. Today's teenagers are satisfied with creating a one-on-one relationship with a computer. They create their own world by interacting with their computers.

\section{Explore for themselves}

They learn more about themselves, what they like and what they don't like through the Internet. This is a huge part of the selfexploration process. The Internet allows them to find more information and helps them become more knowledgeable in the topics that most interest them. Thus, it is much easier to learn who you really are through the help of the Internet.

\section{Are free in emotional and ntellectual self expression}

The cyber world allows these teenagers to share and express their deep emotional feelings and open up intellectually on web boards. To some extent, they carry back home these behaviors of such freedom in expressing and defending their minds which, has made adults view their generation as being rude. 


\section{Are investigative and innovative}

Search engines have become a teenager's best friend. They know that anyone can post things on the web, so they do not believe or just stick to one website for information. Instead, they use search engines to find out about other sources and opinions. This investigation gives them a clearer picture and encourages them to form their own opinions based on the information that they have uncovered on their own. On the other hand, innovative ideas also are simulated by the search function in the Internet. The ways that teenagers learn new things have triggered their creativity and imagination and make it reality.

\section{View the world broadly with an open mind}

During the interviews, many teenagers have mentioned how their generation is shaped to be more open-minded because they see more and learn more about people's differences. Cyberspace has opened their worldview and it has also broadened their minds in ways that make this generation more open than others when it comes to thinking out of the box or accepting differences.

\section{Get connected with their friends, with others, with the world}

More and more teenage activities prove that they like to 'get connected' to others. Calling friends on a cell phone for no reason has become a casual behavior. They also want to know what is going on in their society, including what is happening around the world. Being connected gives these teenagers the sense of being a part of the society they live in, no matter if that society is as small as their close circle of friends or as large as the world community.

\section{Have a new sense of time}

Technology has shaped them to experience a new sense of time. We are moving into an era that when the Internet might not be enough, that a hi-speed Internet connection is what is most desirable! Teenagers reported that the fast response of technology has made them realized how time is one of the most valuable things in life. Waiting on having patience in getting what they want is less than their parent's generation. This is because they are used to the convenience advanced technology provides for them. If loading a new game only takes them seconds, how can they patiently wait to receive a letter through regular mail?

\section{Enjoy multiple identities}

When they go online, these teenagers get a chance to be someone they might not be, including not showing their real identity to others. It is fun just to make up a fake name and use it in a chat room. It is like playing a game where you can be whoever you want to be and try to fool the people on the other side of the screen. A girl can simply go online and discuss heavy topics like politics or fake being a man and court other women. However, some teenagers also reported that they still think sometimes doing these types of things can have negative consequences and they do not enjoy them as they are morally wrong. In sum, they enjoy the new experience of having multiple identities to a certain extent.

\section{Use computers more for leisure than for work}


Teenagers and kids in the computerized generation often use their computers more for leisure purposes than for work. They use computers to reduce stress and entertain themselves. Some may wonder what stress these teenagers have. Most of the teenagers in this study reported their stress often came from school and doing so much homework.

\section{Have high sense of alertness}

This generation of teenagers, whether they like it or not, are automatically alert to news and happenings. This is because news now travels faster in this era. Teenagers like to be a part of what they hear, especially news of others' well-being and wars. This sense of alertness also includes following the trend of new types of high technology. You can often hear question like "When will the new Nokia cell phone addition be out?" or "What does the new model look like?" in teenagers' conversations.

\section{Want options}

The way technology is built has provided this generation with lots of options. Having options makes them feel as if they were making the right decisions for themselves that best suit their needs. No matter if it is a new mobile phone or a new watch that is out, the first thing teenagers will ask is how many options does it have and what can it do. Being familiar with this type of behavior also is extended to their everyday life interaction with other humans, namely their parents, teachers, and other people who they assume should also give them options.

\section{Like things customized}

Everything should be customized according to who they are and to the way they use it and this goes for fashionable clothing as well as advanced technology gadgets. It makes them feel unique because that object was made especially for them. In a world of is mass production, people tend to desire to be unique.

\section{Have their own language}

You can see shorter forms of words, which look like slang or funny symbols, practically in every online conversation. Thai teenagers use this type of language in chat rooms and when they send messages to each other through MSN. The most common reason why they want to create this type of language is because it is easier to communicate with others as you type less. The new word forms are understandable only within this new generation, giving them the sense of secrecy, hip, being in the "in" group, and being different. The new type of language is in two distinguished forms: symbols and slang. Most of the words come from slang teenagers use with friends in real life, sound imitations, or abbreviations. Below are examples of the new type of language. 


\begin{tabular}{|c|c|}
\hline Symbol & Meaning \\
\hline $\mathrm{T} T$ & Sad or crying \\
\hline$-{ }_{-}^{-} " “$ & So tired that you sweat or didn't understand \\
\hline$\wedge \wedge$ & Happy \\
\hline $555+$ & Laugh \\
\hline lol & Teasing, sticking the tongue out or laughing at \\
\hline$>_{0}<$ & Shouting out \\
\hline${ }^{\wedge} 0^{\wedge}$ & Laughing \\
\hline$: \mathrm{P}$ & Teasing, sticking the tongue out or laughing at \\
\hline$-\ldots$ & Stressful \\
\hline$\ldots$ & Don't have anything to say \\
\hline English Word (s) & Meaning \\
\hline D or ddd & Sawaddee, Hi in Thai \\
\hline Bub Bye or by & Bye bye \\
\hline G'nite or Gd nite & Good night \\
\hline $2 \mathrm{U}$ & To you \\
\hline ya & You \\
\hline Chillin' or chill chill & Just hanging out, a "so-so feeling" \\
\hline thx & Thank \\
\hline plz & Please \\
\hline
\end{tabular}

\begin{tabular}{|c|l|}
\hline Thai Word (s) & \multicolumn{1}{c|}{ Meaning } \\
\hline ซุย & $\begin{array}{l}\text { "Sui" means stating that one is boasting or bragging about } \\
\text { things }\end{array}$ \\
\hline ซะงั้น & "Sa-ngan" means "why did it happen this way" \\
\hline เล่นเอ็ม & "Lend-m" means playing MSN \\
\hline กำ & "Khum" means bad karma, paying for one's bad karma \\
\hline ก๊ากกกกกกกกกก & "Kakkkkkkk" means very funny \\
\hline เม้น & "Ment" is an abbreviation of "comment" \\
\hline หุหุ, หึหึ, กิกิ, or อิอิ & "Hu-hu," "Heu-Heu," "Kik-kik," or "Ai-ai" means laughing \\
\hline
\end{tabular}

\section{Form new types of relationships}

Many new types of friendships are formed through the help of advanced technology like the Internet. Unlike writing a letter to a pen pal, correspondence through chatting, MSN, ICQ, QC, and e-mail can establish a much faster friendship and a larger group of friends with the same interests all at once. Establishing a romantic relationship through the Internet is also something these teenagers experience. Many types of relationships have evolved side-by-side with technological advancement. For example, the new form of fan club is another type of modern relationship. Fan club activities in the computerized generation take shape in a new way, besides sending a letter to their favorite celebrity. Teenagers who like the particular celebrity may make a website so that others who like the same celebrity could join in. Activities in this kind of web site include updating pictures of their favorite 
celebrities, writing a biography, and posting on the web the events where that particular celebrity will show up. Similar activities can be found on television too. Reality television also provides a new type of participation for fanatic teenagers to send messages for others to see on screen and vote for their favorite stars.

\section{Learn new skills}

Computer usage provides teenagers with direct and indirect learning skills. The skills these teenagers stated that they learned are such things as English skills, social and conversational skills, typing, screening, searching for information, data entering, analyzing information, using Microsoft programs, namely, Word, Excel, and Power Point, editing pictures through using art and Photoshop programs and problem solving. The skills of making a website, and even playing computer games, provide them with finger and eye coordination skills!

\section{Are addicted to new things}

Like drugs, teenagers can be addicted to many things, such as to playing games, to the Internet, to chat rooms, and to friends.

\section{Setting a new etiquette - 'the netiquette'}

Being in the Internet world also requires a person to behave within the "netiquette rules". These Thai teenagers who often use online services such as chat and posting comments on web board know these shared rules. For example, a person is prohibited to say or post rude words, hack, steal data, capitalized letters (because it implies that you are shouting rudely at the others), post inappropriate pictures on the Net, forward junk mail, send unrelated e-mail to everyone on the e-mail list, and respect other people' s opinions and the website rules.

These are just the main characteristics that computers have brought about on the computerized generation. There may also be other characteristics that are unique to just a small group of teenagers. Moreover, not every teenager will be influenced in all the ways that are listed above. Some may be influenced more than others. It also depends on the individual's personality. For instance, someone who is an extrovert will not find it necessary to be someone else online or use multiple identities. Furthermore, someone who is an introvert will have limits in expressing his/her emotions even if the person on the other side of the screen does not know who they are. However, the majority of the characteristics are interrelated. One will lead to another and so on.

\section{Adult myths concerning teenagers and computers}

During the interviews, teenagers also mentioned that adults in Thai society often have some negative attitudes and false ideas about computers.

"A new creation, like computers, always has a double standard on humans."

The new generation is aware of the fact that everything has two sides. It is up to the user's sense of responsibility which will make things worst or better, but not the machine.

"Computers are luxurious urban accessories that will partly lure 
kids to get addicted to bad things such as pornography and games."

It is not always true that how these teenagers use a computer will have a bad impact on their lives. Teenagers no longer view computers as a luxury machine anymore, because they use them in a very down-to-earth way.

"Computers are best to be used as work-related machines and office machines or for educational purposes rather than other use."

Teenagers think that computers are best to be used in the most optimized way - that is, they should be used in variety of ways than just to use them for work and direct learning purposes. This is where the real value of computers lies. A lot of computer-related activities that teenagers engage in teach them valuable lessons in life and help them grow, and, most of all, those indirect learning experiences are hard to be found elsewhere when both of their parents are working outside the home. In order to survive in this new world (computer and advanced technology world) they need those skills.

"Adults think that we (teenagers) only use computers for entertainment and fun".

This is not always true. Teenagers use their computers for multiple purposes. Although most of the time is for entertainment-related activities, they also use computers to educate themselves by searching for new information, finding their self-identity, and learning indirect skills (using English vocabulary, typing skills, etc.), which all are beneficial to them.

"Computers block teenagers from the outside world of activities."

This might be true if the term 'outside activities' equals physical activities such as playing sports and being in nature. But for these Thai teenagers, computers open up another window of opportunity for their generation that their parents never had and wish to have. To them, meeting new friends, exchanging opinions with people across the globe, and forming their own community composed of people who share the same interests are their meaning of 'outside activities.' As time passes, adults might have to compromise and get used to the new meaning of 'outside activities.'

"Chatting on the Net is nonsense and it is just a waste of time."

Adults would be surprised to friend that often teenagers use chat for beneficial reasons. They make new friends, ask for help in doing homework and, where to search for good sources of information for doing reports, conduct small research projects, ask what the people in the chat room think, and help them make the right decision by consulting others who have experience. 
"Computers can bring harm and danger to children and teenagers."

Although this can be true, teenagers think that their generation is aware of this fact. Their generation has created their own-mechanisms for protecting themselves from harmful things. For example, when they chat on the Internet, they do not give personal information to strangers. If they think there is something suspicious, they consult their parents. They know how to balance their time between playing and working/studying. They do not believe everything they read on the Internet. They use their own judgement about the things they read. Last, they know that using computers too much will damage their vision; therefore, they know they should keep a one-foot distant from the screen and rest their eyes when they have been at the computer for more than two consecutive hours.

"Computer games make your child violent."

Teenagers do not believe this is true. They think what lead kids of their age to be violent is the fact that some kids do not have proper parental guidance, do not have good role models at home, and lack parental love and affection. These reasons are likely to shape teenagers to act aggressively and violently.
"Computers are too high-tech for adults to learn and keep up with. It is just a machine that has no feelings."

Teenagers' advice to this misconception is for adults to open up their minds. Learning new programs is hard for any age. It takes time, patience, and, most of all, a sense of nurturing toward your computer to improve your attitude and help you to learn faster than before.

In summary, teenagers tend to view computers in a more positive way than adults. One of the reasons these teenagers think adults have these negative notions is the news. From time to time, there will be negative news on television and in newspapers giving examples of computer and Internet dangers, which happen in Thai society or Western countries. Examples are how some Thai children and teenagers skip school to play online games, that playing on a computer too much causes grades to drop, children learning about sex and are likely to desire to engage in sexual activities earlier than they should because of viewing pornographic pictures on the Internet, how crimes like kidnapping and luring girls to be raped can happen through Internet chat, and the most common one was children imitate violent acts they see in their computer games in real life.

\section{How we foresee our future living with computers and advanced technologies}

A lot could be learned about one's future through listening to the imagination of others. A part of this study emphasizes valuing the imaginations of this young 
generation who will soon grow up to be future adults, the important source of the country's brain and strength. Often, understanding the imagination of others is a difficult task. The pictorial ethnography techniques can help bridge the understanding of the imaginative description given.

Thai teenagers visualized their future living with computers and advanced technology in similar ways. We would live in a world where computers control everything. We would live a comfortable life where things are done much faster and more conveniently. Every household, even the poor, will own at least one computer. Computers have now become our life.

They see themselves living in a world full of another kind of citizen, robots. Robots are like the fifth means of livelihood, after food, clothes, shelter, and medicine, that humans will not be able to do without. Thai people will start preserving antique Thai-style houses. People will go back to learn more about their traditional religious beliefs to uplift their spirits. Inside the house, we will use computers to control every type of housework. Robots will be our maids and do the tasks housewives used to do. The time we save from not having to do these chores will be used to do other things that we want to do in life. Every function we want in daily life can be done with the use of our mobile phones or wrist watches.

Education will improve a lot due to technology that will help us in visualizing what we learn much more efficiently than reading books. We will develop an advanced technology to improve the visual and audio system. It will be the responsibility of the local government to added new types of welfare for children, such as lessons through the Internet. In the future children will not have to go to school. They will use the Internet instead. They can search for information directly and if they have problems they will e-mail their teachers. Every message such as chat messages, school reports, and e-mailing friends on the other side of the world will be possible through Internet technology. Parents will learn to support their children's use of technology in a proper way. A part of having good parental skills will depend on the level of technological knowledge each parent has and how they teach their children to use it in the right way. Parents will also encourage their children to exercise to keep them healthy.

On the street we might see computers replacing merchants and street vendors. We will not have to drive our car. It will just move according to how we program where we want to go. We will also travel in the air. There would be traffic control in the air as well as on the ground and underground. Time will be very valuable; and therefore, it will be the most important thing for humans. We cannot waste any time because everything will move at a fast pace. Everyone will in a rush, time spent making each decision will crucial because we will live in a more competitive world. We will use transportation that is fast, like the sky train. Cars will also be limited due to the pollution. Thus, most people will have to use public transportation like the sky train and subways.

Food will come in a more processed form, maybe in a can. Canned food will be composed of all the essential nutrients humans need, including added vitamins and minerals. When we are sick we can cure ourselves. There will be no need to go to the hospital and spend an hour waiting for doctors. There will be self-administered medicine in every household cabinet. 
Our physical body might change too. Our head might be larger than other parts of the body. This is because the brain will be used the most. We will lack the exercise of using our arms, legs, etc. We might have computer chips installed in our body. The chip will act like a remote control that will control the brain waves that can send messages to the Internet network. The chip will also be link to computers at home, mobile phones, and other electronic devices that we use. Humans will become lazy as everything will be done using technology. We will have more illnesses and diseases because our health will get worse, as we lack exercise from doing things for ourselves. We will be sitting a lot, become short-sighted, and fatter because we will rely on robots to do everything for us.

The downside to the story is the fact that industrialization and advanced technology will have brought many bad impacts on the environment. They will destroy the water, the air, the soil, and the ecology system that we live in, causing rapid growth of various types of pollution. We will have used up all of the natural resources. However, humans will have found a way to create a new type of technology which will help build a new eco-system that we long for. It is a shame that our future might be limited to the tight space we will have created. Nevertheless, people will be able to travel through different periods of time using a time machine and can live in the time that they want. It will become a cycle where old technology will be used to conduct endless research in the desire to make new advanced technology that is better and can replace the old ones.

Technology will help us fight crime, catch burglars, and discipline people who break the law. We then might have only one government, that is, a world government.
People will have to follow the rules of this organization. We as humans, no matter what race, ethnicity, gender, age, or class, will have to live under the same rules, that is, 'the world law.' Overall, it is still a good world to look forward to.

What these teenagers described not only reflects the picture of their future, but also reflects tomorrow's living conditions based on what they are experiencing today. 
MANUSYA: Journal of Humanities (Special Issue No.8 2004)

Ethnographic pictorial stories of computerized generation's future lives
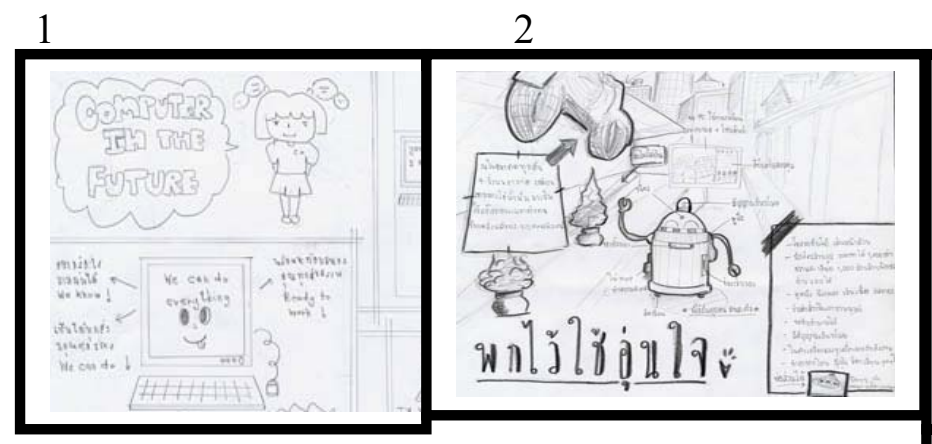

3 


\section{Conclusion}

This research provides insights into various aspects of the Thai computerized generation's life. The way this generation defines themselves gives us a clue as to how they distinguish themselves from other generations in Thai society. The description of their daily life activities highlights the way they utilize computers and advanced technology. Symbolic meanings given to computers by this computerized generation provide us with a deeper understanding of 'why' computers have become an essential part of their lives; whereas, unique characteristics of this very same generation provide us with a better understanding of 'how' computers have become part of their way of living. Living under the globalization trend might have made some of the concepts mentioned as characteristics of the Thai computerized generation seemingly similar to what has been found in Western countries. When one looks closely and digs deeper under the surface, one will find that all of these influences are new to Thai society. Many of the computer-influenced characteristics cause hybridization of the ways these Thai teenagers adopt technology into their lives. Furthermore, the author's decision to include teenagers' voices on the topics of "Adult' Myths Concerning Teenagers and Computers" and "How We Foresee Our Future Living with Computers and Advanced Technologies" serve as an encouragement and an opportunity for these teenagers to have a say on issues which are relevant to their presence in society. In this study, the author has mapped out different aspects in studying the lives of the Thai computerized generation. Future studies could use this research as a foundation in exploring variations of technological and computerrelated impacts on those of different generations, genders, ethnicities, ages, classes, and religious groups in Thai society. Such studies can be put to use in serving the different needs of each group in society.

\section{References}

Anderson, Ben and Karina Tracey. 2001. 'Digital living: The impact (or otherwise) of internet on everyday life'. American Behavioral Scientist, 45(3): 456-475.

Chaddatar Paratasillapin. 2001. Internet use of the pre-computer generation users. M.A.Thesis. Faculty of Communication of Art, Chulalongkorn University.

Dooling, Judith O'Donnell. 2000. 'What students want to learn about computers'. Educational Leadership, October 2000: 20-24.

'Internet users' behaviors'. 2003. Econnews, April 2003: 47-49.

Khanchit Malaiwong (et.al). 1998. The impact of technology on Thai bureaucracy: A research report. Bangkok: The National Electronics and Computer Technology Center.

Komonmas Paradonprateave. 1991. 'The evolution of computer and computer used for educational reasons in Thailand'. Sukothaithaamatiraj Journal, 4(2).

Monchai Sripetchnai. 2004. Factors impact on internet behavior among teenagers in Bangkok. M.A. Thesis Communication of Art, Thammasart University. 
The National Electronics and Computer Technology Center. 1999. How the Thais use their internet?: A survey report. Bangkok: The Center.

-----. 2004. The internet index of Thailand. [http://www.ntl.nectec.or.th/internet/ user-growth.html]. 12 December 2004.

-----. 2002. WWW: Thaiparents.net.net. Bangkok: The Center.

Ongarij Ritthongpitak. 1996. The use of world wide web on internet among university students. M.A.Thesis. Department of Public Relations, Chulalongkorn University.

Ornuma Srisuttipan. 2002. Opinion, media exposure and lifestyle of internet users in Bangkok. M.A. Thesis. Faculty of Communication Arts, Thammasart University.

Pentip Jirapinnusorn. 1997. Searching for information through mass media and internet among college students and university employee. M.A. Thesis. Faculty of Communication of Arts, Chulalongkorn University.

Phetchompu Theppipit. 1990. The relationships between violent behaviors and behaviors of reading cartoon books: Viewing television shows and playing computer games of the six grade students in Bangkok. M.A. Thesis. Department of Telecommunication, Faculty of Education, Chulalongkorn University.
Piyanat, Pondper 1999. 'Peaking at the internet user behaviors'. E-commerce, December 1999: 49-50.

Pituma Puntawee. 1999. 'Guess...Who use the internet'. IT Pritat, 7(6): 7-11.

Sarawut Puntuwong. 2003. Receptive behavior: Awareness and utilization of Thai-web sites from teenager in Bangkok area. M.A. Thesis. Faculty of Communication Arts, Thammasart University

Sirintorn Chaisakda. 2002. 'Survey result of internet user in Thailand in the year 2001'. IT Praritat, 10(3-4): 5-8.

Srichan Changwattanachai. 1991. 'The roles of computer in Thailand'. Saamitsan, July-August: 89-94.

Srisab, Punsak. 1999. 'Internet and the elderly people'. Computer Today, September 1999: 92-97.

The survey of information technology: Report results on the usage of advanced technology. 2003. Bangkok: the National Electronics and Computer Technology Center.

Tapscott, Don. 1998. Growing up digital: The rise of the net generation. New York: McGraw-Hill.

Thanat Kaseamchaiyanand. 2001. The factors that effect web site accessing behavior of internet users in Bangkok. M.A.Thesis, Faculty of Communication of Arts, Thammasart University. 
Tiotuyco, Gonnzalo P. and Pakorn Vichyanond.1985. 'Computerization: It all began with a pair'. Thailand Business, September 1985: 36-44.

Williams, M. Samuel and Leighton C. Peterson. 2002. 'The anthropology of online communities'. Annual Review Anthropology 31: 449-67. 